\title{
Karakteristik Literasi Keuangan (Studi Kasus Mahasiswa Fakultas Ekonomi Universitas Sarjanawiyata Tamansiswa)
}

\author{
Elisabet Yuli Kristanti ${ }^{\mathrm{a}}$, Risal Rinofah ${ }^{\mathrm{b}}$ \\ ${ }^{a}$ Universitas Sarjanawiyata Tamansiswa, yulielisa2107@gmail.com

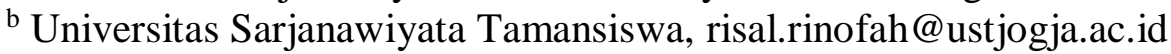

\begin{abstract}
A b s t r a k
Literasi keuangan pada individu menjadi ketertarikan tersendiri bagi seseorang, karena dapat mempengaruhi proses pengambilan keputusan bagi seseorang secara lebih efisien, teliti dan rasional. Seiring dengan perkembangan teknologi juga yang semakin canggih seharusnya bisa dimanfaatkan seseorang untuk menambah wawasan dan bahan untuk media belajar, sehingga bisa mengelola keuangan yang baik sejak dini, dan nantinya semakin siap dalam menghadapi dunia kerja. Penelitian ini memiliki tujuan untuk menguji tingkat literasi keuangan mahasiswa dan faktor yang mempengaruhi seperti karakteristik demografis serta perilaku keuangan. Penelitian ini memiliki responden sebanyak 150 mahasiswa yang berasal dari jurusan Manajemen dan Akuntansi Fakultas Ekonomi Universitas Sarjanawiyata Tamansiswa. Penelitian ini menggunakan kuesioner dengan indikator literasi keuangan meliputi: pengetahuan umum keuangan pribadi, pengetahuan manajemen uang, asuransi, dan investasi. Metode analisis yang digunakan dalam penelitian ini adalah statistik deskriptif, uji asumsi klasik, dan analisis regresi linier berganda. Hasil pengolahan statistik deskriptif menunjukkan jika tingkat literasi keuangan mahasiswa tinggi, yaitu 69,73 persen. Hasil dari analisis regresi linier berganda menunjukkan bahwa jenis kelamin, usia, tahun masuk, tempat tinggal, perilaku keuangan berpengaruh positif dan signifikan terhadap literasi keuangan, sedangkan pendapatan berpengaruh negatif dan signifikan terhadap literasi keuangan mahasiswa.
\end{abstract}

Kata Kunci: Literasi keuangan, faktor demografi dan perilaku keuangan.

\section{A b s tract}

Financial literacy in individuals becomes a special interest for someone, because it can affect the decision-making process for someone more efficiently, thoroughly and rationally. Along with the development of technology which is also increasingly sophisticated, someone should be able to add insight and material for learning media, so that they can manage finances well from an early age, and will be more ready to face the world of work. This study aims to examine the level of student financial literacy and influencing factors such as demoraphic characteristics and financial behavior. This study have respondents as many as 150 students who come from the Department of Management and Accounting, Faculty of Economics, University of Sarjanawiyata Tamansiswa. This study uses a questionnaire with indicators of financial literacy including: general knowledge of personal finance, knowledge of money management, insurance, and investment. The analysis method used in this research is descriptive statistics, classical assumption test, and multiple linear regression analysis. The results of descriptive statistical processing show that the level of student financial literacy is high, namely 69.73 percent. The results of the multiple linear regression analysis show that gender, age, year of entry, place of residence, financial behavior have a positive and significant effect on financial literacy, while income has a negative and significant effect on student financial literacy.

Keywords: Financial literacy, demographic factors and financial behavior.

\section{Pendahuluan}

Dimasa seperti ini literasi keuangan pada individu menjadi ketertarikan tersendiri bagi seseorang karena dapat mempengaruhi proses pengambilan keputusan bagi seseorang 
secara lebih efisien, teliti dan rasional (Lusardi \& Mitchell, 2011). Studi lainnya yang menguatkan penelitian yaitu bahwa tingkat literasi keuangan seseorang mempunyai hubungan dengan tingkat kesejahteraan dimasa sekarang dan dimasa mendatang (Kusumawardhani \& Cahyani, 2020). Pemahaman mengenai pesntingnya literasi keuangan yang baik, tidak hanya untuk orang dewasa yang sudah bekerja namun juga bagi mahasiswa sebagai penerus kaum muda sebelum memasuki dunia kerja. Karena jika mahasiswa milenial tidak memahami literasi keuangan dengan baik maka akan berdampak pada kesejahteraan seseorang serta berdampak dalam pengambilan keputusan di masa mendatang, dilingkungan keluarga maupun pada dunia kerja, Masigul dalam (Kusumawardhani \& Cahyani, 2020).

Seiring dengan perkembangan teknologi juga yang semakin canggih seharusnya bisa dimanfaatkan seseorang untuk menambah wawasan dan bahan untuk media belajar, sehingga bisa mengelola keuangan yang baik sejak dini, dan nantinya semakin siap dalam menghadapi dunia kerja, namun kebiasaan generasi muda saat ini kurang sadar tentang pentingnya pemahaman literasi keuangan. Dalam mengambil keputusan harus dilakukan secara rasional dan menjadikan informasi sangat penting bahwa generasi muda harus memiliki pengetahuan bagaimana mengambil keputusan dengan baik, supaya tidak salah langkah dalam mengambil keputusan.

Rosackers et al., (2009) mengungkapkan bahwa financial literacy merupakan kemampuan seseorang untuk memahami, mengatur, menganalisis, dan menjelaskan mengenai masalah dalam keuangan. Oleh karena itu, literasi keuangan mengutamakan pada pengetahuan dan keterampilan seseorang untuk menghadapi masalah dalam keuangan dan membuat keputusan di setiap waktu. Jika seseorang memiliki literasi keuangan yang baik, maka akan berdampak pada efektivitas alokasi keuangan dan mampu membuat keputusan keuangan secara cermat serta terampil (Kusumawardhani \& Cahyani, 2020).

Sakinah \& Mudakir (2018), hasil penelitiannya menyatakan bahwa tingkat literasi mahasiswa Universitas Diponegoro masih rendah yaitu sebesar 50,4\% dan yang tidak mempengaruhi financial literacy yaitu jenis kelamin dan penghasilan, sedangkan yang berpengaruh terhadap financial literacy adalah pendidikan orang tua, lama studi, usia, IPK, lama studi (Sakinah \& Mudakir, 2018). Margaretha \& Pambudhi (2015) menjelaskan jika yang berpengaruh terhadap financial literacy yaitu variabel gender, IPK, tempat tinggal, usia, pendidikan dan pendapatan orang tua, tahun masuk (Margaretha \& Pambudhi, 2015).

Beberapa studi terdahulu mengungkapkan bahwa pengetahuan dan keterampilan seseorang tentang literasi keuangan pada mahasiswa rata-rata masih rendah, khususnya pada kesadaran dari mahasiswa untuk mempelajari literasi keuangan. Literasi keuangan sangat penting sekali bagi para generasi muda saat ini, karena dapat meningkatkan kualitas keuangan dimasa yang akan datang dan mengatasi berbagai tantangan dimasa mendatang yang cukup berat. Dengan adanya penelitian mengenai literasi keuangan ini diharapkan untuk meningkatkan kemampuan mahasiswa dan pemahaman mahasiswa 
tentang literasi keuangan sehingga generasi muda akan semakin siap untuk menghadapi persaingan dalam dunia kerja maupun dalam berkeluarga.

Dengan demikian, peneliti berminat untuk melakukan penelitian tentang analisis tingkat financial literacy dan pengaruhnya terhadap literasi keuangan mahasiswa Fakultas Ekonomi UST. Yang melibatkan mahasiswa S1 program studi manajemen dan akuntansi Fakultas Ekonomi UST. Penelitian ini bertujuan untuk menguji pengaruh jenis kelamin, usia, tahun masuk, pendapatan, tempat tinggal, dan perilaku keuangan mahasiswa terhadap literasi keuangan. Adapun manfaat praktis penelitian ini yaitu mahasiswa dapat memperoleh informasi tentang financial literacy, sehingga mahasiswa bisa mengambil keputusan dengan baik dan benar untuk kesejahteraan dimasa mendatang.

\section{Landasan Teori}

\subsection{Literasi Keuangan}

Masalah dalam keuangan bukan hanya karena dari pendapatan yang rendah. Masalah dalam keuangan juga muncul akibat dari kurang teliti dalam mengelola keuangan sehingga tidak bisa menentukan keputusan keuangan dengan baik, kesulitan financial bisa mengakibatkan seseorang menjadi stress, tidak bisa menentukan arah tujuan hidup, tidak percaya diri, bahkan jika pasangan suami istri bisa berujung pada perselisihan hingga perceraian (Krishna et al., 2010). Literasi keuangan berkaitan dengan manajemen keuangan seseorang karena jika semakin tinggi pemahaman tentang literasi keuangan maka semakin baik manajemen keuangan sehingga semakin berhati-hati dalam mengambil keputusan keuangan (Laily, 2016).

Literasi keuangan merupakan kemampuan seseorang untuk membaca, menganalisis, mengelola serta mengkomunikasikan kondisi keuangan yang dimiliki maka dapat mempengaruhi kesejahteraan hidup seseorang, Nurhayati \& Kuningan dalam (Nurhayati \& Wiharno, 2020). Literasi keuangan juga didefinisikan sebagai kemampuan seseorang dalam membedakan pembiayaan yang dilakukan, tidak cemas jika berbicara tentang keuangan, serta merencanakan keuangan masa depan yang dapat mempengaruhi dalam pengambilan keputusan keuangan sehari-hari (Nurhayati \& Wiharno, 2020). Adanya literasi keuangan dapat membantu meningkatkan pemahaman mengenai masalah keuangan sehingga bisa membuat keputusan keuangan dengan tepat (Bhushan \& Medury, 2013).

\subsection{Karakteristik Demografi dan Literasi Keuangan}

Hasil dari studi terdahulu tentang literasi keuangan pada mahasiswa sampai saat ini mengatakan bahwa pengetahuan dan pemahaman literasi keuangan mahasiswa rata-rata masih rendah yaitu sebagian besar berada di bawah 60\% (Lusardi \& Mitchell, 2011); (Ulfatun et al., 2016). Terdapat dua faktor yang dapat mempengaruhi literasi keuangan menjadi rendah yaitu faktor dari internal dan eksternal, kategori dari kedua faktor tersebut adalah faktor demografis (Chen \& Vlope, 1998; Worthington, 2006), keterlibatan dari orang tua (Widayati, 2012), kondisi dari ekonomi (Worthington, 2006). 
Jenis kelamin baik laki-laki maupun perempuan tidak mempengaruhi literasi keuangan, namun menurut Krishna et al., (2010); Nurhayati et al., (2020); Margaretha \& Pambudhi (2015); Laily (2016) laki-laki memiliki tingkat literasi keuangan tergolong lebih rendah dari pada perempuan, karena berdasarkan studi terdahulu menunjukkan jika pengetahuan, perilaku dan sikap yang dimiliki perempuan dalam keuangan lebih tinggi dari pada laki-laki. Sebaliknya penelitian Maulani (2016) menjelaskan bahwa tingkat literasi keuangan laki-laki lebih tinggi dari pada perempuan. Rata-rata tidak ada perbedaan antara laki-laki dan perempuan mengenai literasi keuangan, namun perbedaannya hanya terdapat pada aspek manajemen keuangan yang dimiliki masingmasing individu (Kusumawardhani \& Cahyani, 2020). Nababan \& Sadalia (2012), mengungkapkan bahwa tingkat literasi keuangan pada laki-laki lebih tinggi karena lakilaki cenderung lebih mudah menentukan pilihan dalam berinvestasi tidak banyak pertimbangan yang dilakukan, untuk itu laki-laki menurut studi terdahulu dapat dikategorikan mandiri, tidak mudah emosional, lebih percaya diri dan mudah dalam menentukan keputusan yang dipilih (Nababan \& Sadalia, 2012).

Studi terdahulu tentang pengaruh usia terhadap literasi keuangan penelitian Laily (2016); Bhrushan \& Medury (2013); Krisna et al., (2007), bahwa tingkat literasi keuangan tidak dapat diukur dengan kemampuan seseorang berdasarkan dengan usia. Menurut Margaretha \& Pambudhi (2015), mengungkapkan bahwa tingkat literasi keuangan pada mahasiswa dapat dipengaruhi oleh usia seseorang. Menurut Maulani (2016), tentang tahun angkatan pada mahasiswa menunjukkan bahwa tingkat literasi keuangan kalangan mahasiswa manajemen tidak dipengaruhi oleh tahun angkatan dari mahasiswa masuk pada perguruan tinggi. Hasil penelitian Margaretha \& Pambudhi (2015); Krishna et al., (2010) juga mengungkapkan bahwa tahun angkatan mahasiswa masuk tidak terbukti memiliki pengaruhnya terhadap literasi keuangan. Berdasarkan tingkatan mahasiswa masuk menunjukkan bahwa tingkat literasi keuangan dapat diukur dengan tahun angkatan mahasiswa masuk perguruan karena mahasiswa pada semester atas memiliki pengetahuan, sikap, perilaku dalam keuangan dan tingkat literasi keuangannya lebih tinggi dari pada mahasiswa baru (Nurhayati \& Wiharno, 2020).

Pendapatan yang diperoleh dari orang tua tidak mempengaruhi litersi kauangan mahasiswa. Nurhayati et al., (2020), pendapatan yang berasal dari orang tua mengungkapkan bahwa tingkat literasi keuangan pada mahasiswa hampir tidak ada perbedaan yang signifikan berdasarkan tingkat pendapatan dari orang tuanya. Pendapatan yang dimiliki seseorang yaitu positif dan signifikan terhadap literasi keuangan, sehingga dapat meningkat secara non-linier, namun pada nilai dolar terjadi secara monoton (Worthington, 2006). Menurut Susanti (2016) jika pendapatan berpengaruh negatif signifikan terhadap literasi keuangan mahasiswa.

Studi terdahulu tentang tempat tinggal menurut Maulani (2016); Nababan \& Sadalia (2012) mengungkapkan bahwa tingkat literasi keuangan dapat dipengaruhi oleh tempat tinggal seorang mahasiswa, karena mahasiswa yang bertempat tinggal di kos/kontrakan/asrama memiliki tingkat literasi keuangannya lebih tinggi dibandingkan dengan mahasiswa yang tinggal di rumah bersama orang tua/keluarga. Tingkat literasi 
keuangan pribadi pada mahasiswa yang hidup sendirian di kos, kontrakan, maupun asrama lebih tinggi dari pada mahasiswa yang hidup atau bertempat tinggal bersama orang tuanya, karena mahasiswa yang tinggal bersama orang tua biasanya kurang mandiri dan dalam mengelola keuangan mahasiswa yang tinggal sendiri biasanya mampu mengatur dan mengelola keuangan pribadi untuk memenuhi kebutuhan sehari-hari. Mahasiswa yang tempat tinggalnya jauh dari Universitas/Perguruan tinggi maka memilih untuk tinggal sendirian seperti kos, kontrak, atau tinggal di asrama, ini yang dapat menjadikan mahasiswa mandiri tidak bergantung dengan orang tua karena harus bisa mengelola keuangan sendirian supaya uang pemberian dari orang tua bisa mencukupi kebutuhan sehari-hari sampai orang tua memberi kembali, jika mahasiswa dari golongan atas seharusnya mampu menyisipkan uang untuk ditabung atau berinvestasi sehingga bisa menunjang kebutuhan dimasa depan (Maulani, 2016).

\subsection{Perilaku Keuangan dan Literasi Kuangan}

Perilaku keuangan dapat dikatakan baik apabila tinggi tingkat literasi keuangan yang dimiliki seseorang (Herawati, 2015). Literasi keuangan didefinisikan sebagai pengetahuan dan kemampuan seseorang dalam mengelola keuangan, supaya tidak mengalami masalah pada keuangan. Trade off merupakan masalah yang sering dihadapi oleh seseorang karena sebagian orang mengalami situasi dimana harus mengorbankan satu barang untuk mendapatkan barang yang lainnya, namun terkadang dibatasi oleh ekonomi seseorang untuk memperoleh barang yang diinginkan (Herawati, 2015).

Literasi keuangan pada seseorang tidak dipengaruhi oleh perilaku keuangan, karena perilaku keuangan tidak bisa menentukan tujuan dan perencanaan keuangan seseorang secara baik namun berdampak pada proses perencanaan dalam jangka panjang dan pendek. Oleh karena itu, mahasiswa yang tidak dapat membuat perencanaan dengan baik sehingga akan terburu-buru dalam mengambil keputusan untuk membeli suatu barang. Perencanaan keuangan sangat penting, karena jika melakukan transaksi (pengeluaran) dalam keuangan sesuai dengan tujuan penggunaan keuangan dan akan berdampak pada kehidupan masing-masing individu dalam penggunaan keuangan. Berikut beberapa karakter yang bisa dilakukan oleh mahasiswa berkaitan dengan perilaku yang baik dalam mengelola keuangan yaitu tepat waktu dalam membayar tagihan bulanan (misalnya: membayar uang kos, listrik, air, sampah, uang kuliah), membuat anggaran dalam belanja (misalnya: memenuhi kebutuhan sehari-hari, belanja bulanan), mencatat semua pengeluaran (misalnya: servis motor, belanja bulanan, membayar kos), dan menabung sebagian uangnya untuk memenuhi kebutuhan yang akan datang tak terduga (Pahrudin et al., 2018).

\section{Metode Penelitian}

Berdasarkan dari tujuan dan sifat masalah dalam penelitian maka jenis penelitian ini menggunakan statistik deskriptif dan kuantitatif yaitu digunakan untuk mengetahui tingkat literasi keuangan dan apa saja yang mempengaruhi perilaku keuangan pada mahasiswa Fakultas Ekonomi Universitas Sarjanawiyata Tamansiswa. Variabel dependen yang digunakan dalam penelitian yaitu literasi keuangan. Variabel independen 
yang digunakan dalam penelitian ini adalah jenis kelamin, usia, tahun angkatan, pendapatan, tempat tinggal dan perilaku keuangan. Populasi merupakan cakupan keseluruhan objek maupun subjek serta individu yang terdapat pada wilayah yang akan diteliti (Hamid \& Patra, 2019). Populasi yang digunakan dalam penelitian ini adalah mahasiswa Fakultas Ekonomi angkatan 2017 - 2020 Universitas Sarjanawiyata Tamansiswa denganjumlah 240 Mahasiswa.

Sampel merupakan bagian dari populasi yang terpilih yang diperoleh berdasarkan berdasarkan dengan prosedur tertentu yang dapat merepresentasikan populasi (Hamid \& Patra, 2019). Sehingga berdasarkan pada perhitungan sampel menggunakan rumus slovin, diperoleh sampel penelitian sebanyak 150 responden mahasiswa aktif angkatan 2017 2020. Teknik dalam pengambilan data untuk penelitian menggunakan kuesioner dengan menggunakan pedoman dari (Chen \& Volpe, 1998). Pendekatan yang digunakan untuk pengambilan sampel yaitu teknik convenience sampling. Alasan memilih teknik ini karena memudahkan dalam mengambil sampel dan dalam pengambilan data dengan mekanisme penyebaran kuesioner melalui google from. Sebelum data dianalisis terlebih dahulu dilakukan uji validitas dan reliabilitas pada kuesioner penelitian. Teknik analisis yang digunakan pada penelitian ini adalah analisis deskriptif dan regresi linier berganda.

\section{Hasil dan Pembahasan}

\subsection{Analisis Regresi Linier Berganda}

Untuk menguji jenis kelamin, usia, tahun masuk, pendapatan, tempat tinggal, perilaku keuangan terhadap literasi keuangan mahasiswa menggunakan analisis regresi linier berganda. Dalam analisis regresi linier berganda ini akan diuji secara parsial (uji t).

\section{Tabel 1}

Analisis Regresi Linier Berganda

\begin{tabular}{lllll}
\hline Variabel & B & t hitung & Sig t & Keterangan \\
\hline Contant & 21.643 & 3.943 & 0.000 & \\
Jenis Kelamin & 1.756 & 2.379 & 0.019 & Signifikan \\
Usia & 3.894 & 2.905 & 0.004 & Signifikan \\
Tahun Masuk & 1.138 & 2.128 & 0.035 & Signifikan \\
Pendapatan &,- 752 & -2.127 & 0.035 & Signifikan \\
Tempat Tinggal & 1.897 & 2.566 & 0.011 & Signifikan \\
Perilaku & 0.842 & 9.611 & 0.000 & Signifikan \\
Keuangan & & & & \\
\hline
\end{tabular}

Sumber: data primer diolah, 2021.

Berdasarkan informasi hasil analisis pada tabel 1, dapat disusun persamaan regresi linier berganda sebagai berikut:

$\mathrm{Y}=21,643+1,756 \mathrm{X} 1+3,894 \mathrm{X} 2+1,138 \mathrm{X} 3-0,752 \mathrm{X} 4+1,897 \mathrm{X} 5+0,842+\mathrm{e}$

1) Konstanta (a) sebesar 21,643 sehingga menyatakan bahwa jika tanpa adanya variabel jenis kelamin, usia, tahun masuk, pendapatan, tempat tinggal, dan perilaku keuangan, maka rata-rata dari literasi keuangan mahasiswa Fakultas Ekonomi Universitas Sarjanawiyata Tamansiswa mengalami peningkatan sebesar 21, 643. 
2) Koefisien regresi jenis kelamin sebesar 1,756 berpengaruh signifikan, maka dapat dinyatakan bahwa mengalami penambahan poin sebesar 1 , sehingga menyebabkan meningkatnya literasi keuangan sebesar 1,756.

3) Koefisien regresi usia sebesar 3,894 berpengaruh signifikan, maka dapat dinyatakan bahwa mengalami penambahan poin sebesar 1, sehingga menyebabkan meningkatnya literasi keuangan sebesar 3,894.

4) Koefisien regresi tahun masuk sebesar 1,138 berpengaruh signifikan, maka dapat dinyatakan bahwa mengalami penambahan poin sebesar 1, sehingga dapat menyebabkan meningkatnya literasi keuangan sebesar 1,138.

5) Koefisien regresi pendapatan sebesar - 0,752 berpengaruh signifikan, maka dapat dinyatakan bahwa mengalami bertambah 1 poin, sehingga literasi keuangan akan mengalami penurunan sebesar - 0,752.

6) Koefisien regresi tempat tinggal sebesar 1,897 berpengaruh signifikan, maka dapat dinyatakan bahwa mengalami bertambah 1 poin, sehingga menyebabkan meningkatnya literasi keuangan sebesar 1,897.

7) Koefisien regresi perilaku keuangan sebesar 0,842 berpengaruh signifikan, maka dapat dinyatakan bahwa mengalami bertambah 1 poin, sehingga menyebabkan meningkatnya literasi keuangan sebesar 0,842 .

Berdasarkan pada tabel 4.15 di atas, merupakan hasil dari uji t sehingga dapat ditentukan adanya penjelasan pembuktian hipotesis penelitian yaitu sebagai berikut:

\subsection{Pengujian Hipotesis Penelitian}

\subsubsection{Pengujian Hipotesis 1}

Pengujian pada hipotesis yang pertama memiliki tujuan untuk menguji jenis kelamin terhadap literasi keuangan mahasiswa. Tabel 1 diatas menunjukkan variabel jenis kelamin mempunyai koefisien regresi sebesar 1,756 bertanda positif, artinya jenis kelamin (lakilaki dan perempuan) dapat meningkatkan literasi keuangan pada mahasiswa. Pada variabel jenis kelamin dapat diketahui nilai t-hitung sebesar 2,379 dengan nilai signifikan sebesar 0,019. Karena nilai t-hitung lebih besar dari t-tabel yaitu sebesar 1,976 dan nilai signifikan lebih kecil dari 0,05, maka dapat disimpulkan bahwa variabel jenis kelamin berpengaruh positif terhadap literasi keuangan mahasiswa.

\subsubsection{Pengujian Hipotesis 2}

Pengujian pada hipotesis kedua memiliki tujuan untuk menguji usia terhadap literasi keuangan mahasiswa. Tabel 4.15 di atas menunjukkan variabel usia mempunyai koefisien regresi sebesar 3,894 dan bertanda positif, artinya usia mahasiswa dapat meningkatkan literasi keuangan. Pada variabel usia dapat diketahui nilai t-hitung sebesar 2,905 dengan nilai signifikansi sebesar 0,004 . Karena nilai t-hitung lebih besar dari t-tabel yaitu sebesar 1,976 dan nilai signifikan lebih kecil dari 0,05, maka dapat disimpulkan bahwa variabel usia berpengaruh positif terhadap literasi keuangan mahasiswa.

\subsubsection{Pengujian Hipotesis 3}

Hipotesis ketiga memiliki tujuan untuk menguji tahun masuk terhadap literasi keuangan mahasiswa. Tabel 4.15 di atas menunjukkan bahwa variabel tahun masuk mempunyai 
koefisien regresi sebesar 1,138 dan bertanda positif, artinya tahun masuk dapat meningkatkan literasi keuangan. Pada variabel tahun masuk dapat diketahui nilai t-hitung sebesar 2,128 dengan nilai signifikansi sebesar 0,035. Karena nilai t-hitung lebih besar dari t-tabel yaitu sebesar 1,976 dan nilai signifikan lebih kecil dari 0,05, maka dapat disimpulkan bahwa variabel tahun masuk berpengaruh positif terhadap literasi keuangan mahasiswa.

\subsubsection{Pengujian Hipotesis 4}

Hipotesis keempat memiliki tujuan untuk menguji pendapatan terhadap literasi keuangan mahasiswa. Tabel 4.15 di atas menunjukkan bahwa variabel pendapatan mempunyai koefisien regresi sebesar $(-0,752)$ dan bertanda negatif, artinya jika pendapatan yang diperoleh dan jumlah uang saku setiap bulannya meningkat maka literasi keuangan mahasiswa akan menurun. Pada variabel pendapatan dapat diketahui nilai t-hitung sebesar (-2.127) dengan nilai signifikan 0,035. Karena t-hitung lebih besar dari t-tabel yaitu sebesar 1,976 dan nilai signifikan lebih kecil dari 0,05 maka dapat disimpulkan bahwa variabel pendapatan berpengaruh negatif terhadap literasi keuangan.

\subsubsection{Pengujian Hipotesis 5}

Hipotesis kelima memiliki tujuan untuk menguji tempat tinggal terhadap literasi keuangan mahasiswa. Tabel 4.15 di atas menunjukkan bahwa variabel tempat tinggal mempunyai koefisien regresi sebesar 1,897 dan bertanda positif, artinya tempat tinggal dapat meningkatkan literasi keuangan mahasiswa. Pada variabel tempat tinggal dapat diketahui nilai t-hitung sebesar 2,566 dengan nilai signifikan 0,01. Karena nilai t-hitung lebih besar dari t-tabel yaitu sebesar 1,976 dan nilai signifikan lebih kecil dari 0,05, maka dapat disimpulkan bahwa variabel tempat tinggal berpengaruh positif terhadap literasi keuangan.

\subsubsection{Pengujian Hipotesis 6}

Hipotesis keenam memiliki tujuan untuk menguji perilaku keuangan terhadap literasi keuangan mahasiswa. Tabel 4.15 di atas menunjukkan bahwa variabel perilaku keuangan mempunyai koefisien regresi sebesar 0,842 dan bertanda positif, artinya perilaku keuangan dapat meningkatkan literasi keuangan mahasiswa. Pada variabel perilaku keuangan dapat diketahui nilai t-hitung sebesar 9,611 dengan signifikan sebesar 0,000. Karena nilai t-hitung lebih beesar dari t-tabel yaitu sebesesar 1,976 dan nilai signifikan lebih kecil dari 0,05, maka dapat disimpulkan bahwa variabel perilaku keuangan dapat berpengaruh positif terhadap literasi keuangan mahasiswa.

\section{Tabel 2}

Hasil Koefisien Determinasi

\begin{tabular}{lllll}
\hline Model & R & R Square & $\begin{array}{l}\text { Adjusted } \\
\text { R Square }\end{array}$ & $\begin{array}{l}\text { Std. } \\
\text { off } \\
\text { Estimate }\end{array}$ \\
\hline 1 & $0.662^{\mathrm{a}}$ & 0.438 & 0.414 & 4.377 \\
\hline
\end{tabular}

Predictors: (Constant), Jenis Kelamin, Usia, Tahun Masuk, Pendapatan, Tempat Tinggal, Perilaku Keuangan

Sumber: data primer diolah, 2021 
Berdasarkan data (tabel 2), menunjukkan nilai adjusted $R$ square sebesar 0,414, maka hal ini berarti 41,4\% tingkat literasi keuangan dapat dipengaruhi oleh jenis kelamin, usia, tahun masuk, pendapatan, tempat tinggal dan perilaku keuangan, sedangkan sisanya yaitu $58,6 \%$ dapat dipengaruhi oleh variabel lain yang tidak diteliti oleh peneliti.

\subsection{Pembahasan}

Berdasarkan data di atas menunjukkan adjusted $R$ square sebesar 0,414, maka hal ini berarti 41,4\% tingkat literasi keuangan dapat dipengaruhi oleh jenis kelamin, usia, tahun masuk, pendapatan, tempat tinggal dan perilaku keuangan, sedangkan sisanya yaitu 58,6\% dapat dipengaruhi oleh variabel lain yang tidak diteliti oleh peneliti seperti penelitian Rasyid (2012) nilai Adjusted $R$ Square hasil penelitiannya menunjukkan 75,9\% dengan menggunakan variabel literasi pengeluaran, literasi kredit, literasi intervestasi dan literasi tabungan yang dapat berpengaruh terhadap keputusan keuangan dan pengelolaan keuangan mahasiswa (Rasyid, 2012).

\subsubsection{Pengaruh jenis kelamin terhadap literasi keuangan Mahasiswa}

Berdasarkan hasil dari pengujian tersebut dapat menunjukkan bahwa koefisien regresi dari jenis kelamin sebesar 1,756 bertanda positif artinya jenis kelamin (laki-laki dan perempuan) dapat meningkatkan literasi keuangan. Hasil dari uji t menunjukkan bahwa nilai t-hitung sebesar 2,379 lebih besar dari t-tabel sebesar 1,976 artinya variabel jenis kelamin berpengaruh positif terhadap literasi keuangan. Dapat dilihat pada tabel 4.15 diketahui nilai t-hitung sebesar 2,379 dan probabilitas (p) 0,019 $<0,05$ maka jenis kelamin memiliki pengaruh yang signifikan terhadap literasi keuangan mahasiswa. Sehingga hasil dari penelitian ini menjelaskan bahwa jenis kelamin berpengaruh positif dan signifikan terhadap literasi keuangan mahasiswa, sehingga hipotesis yang pertama diterima. Penelitian ini dapat diketahui bahwa tingkat literasi keuangan mahasiswa perempuan lebih tinggi dari laki-laki. Hasil dari uji statistik deskriptif faktor demografi jenis kelamin terhadap literasi keuangan membuktikan bahwa pemahaman tentang literasi keuangan mahasiswa perempuan (50,7\%) lebih tinggi dibanding laki-laki (49,3\%). Dikarenakan mahasiswa laki-laki kurang bersungguh-sungguh dalam mempelajari kaitanya dengan perencanaan dan konsep dalam mengelola keuangan. Begitu sebaliknya tingkat literasi keuangan mahasiswa perempuan lebih tinggi karena perempuan lebih teliti dalam mengambil keputusan dan mengelola keuangan dengan baik, sehingga tingkat pengetahuan perempuan lebih tinggi maka tingkat pemahaman perempuan cenderung lebih luas.

Hasil dari penelitian ini sejalan dengan studi yang dilakukan oleh Wijayanti et al., (2016) memiliki pengaruh positif dan signifikan terjadap literasi keuangan, yang menjelaskan bahwa perempuan memiliki tingkat literasi keuangan yang lebih tinggi dari pada laki-laki. Studi terdahulu dari Maulani (2016); Margaretha \& Pambudhi (2015) Brushan et al., (2013); Krishna et al., (2010), menunjukkan bahwa jenis kelamin berpengaruhberpengaruh positif dan signifikan terhadap literasi keuangan dan perempuan tingkat literasi keuangannya lebih tinggi dari pada laki-laki. Penelitian Hartanti (2018) menjelaskan bahwa terdapat pengaruh jenis kelamin terhadap literasi keuangan asuransi syariah kemudian, laki-laki dan perempuan tidak ada perbedaan tang signifikan terhadap 
literasi keuangan. Menurut Nurulhuda \& Lutfiati (2020) mengungkapkan bahwa jenis kelamin memili pengaruh yang signifikan terhadap lierasi keuangan (Nurulhuda \& Lutfiati, 2020).

\subsubsection{Pengaruh usia terhadap literasi keuangan mahasiswa}

Berdasarkan pada hasil pengujian tersebut dapat menunjukkan bahwa koefisien regresi dari variabel usia sebesar 3,894 dan bertanda positif, artinya usia mahasiswa dapat meningkatkan literasi keuangan. Hasil dari uji t menunjukkan bahwa nilai t-hitung sebesar 2,905 lebih besar dari t-tabel sebesar 1,976, artinya variabel usia berpengaruh positif terhadap literasi keuangan mahasiswa. Dapat dilihat pada tabel 4.15 diketahui nilai t-hitung sebesar 2,905 dan probabilitas (p) 0,004 < 0,05 maka usia berpengaruh signifikan terhadap literasi keuangan mahasiswa.

Hasil dari penelitian dapat disimpulkan bahwa usia berpengaruh positif dan signifikan terhadap literasi keuangan mahasiswa, sehingga hipotesis yang kedua diterima. Sejalan dengan penelitian Hartanti (2018); Margaretha \& Pambudhi (2015); Krishna et al., (2010); Maulani (2016), menjelaskan bahwa usia secara positif dan signifikan memiliki pengaruh terhadap literasi keuangan. Hasil dari uji deskriptif menunjukkan bahwa mahasiswa yang berusia $<20$ tahun merupakan kategori tingkat literasi rendah $(10,7 \%)$, sedangkan mahasiswa yang berusia 20 sampai 30 tahun dapat dikategorikan tingkat literasinya tinggi yaitu sebesar 89,3\%, artinya mahasiswa pada era sekarang siklus dari keuangannya tidak memiliki masalah yang kaitanya dengan pengetahuan tentang keuangan, pengelola keuangan, investasi, dan asuransi. Selain itu menurut Chen \& Volpe (1998) mengungkapkan bahwa seseorang yang berusia 18 sampai 22 tahun tingkat literasi keuangannya rendah, karena orang yang berusia dibawah 30 merupakan siklus tahap pertama yaitu mereka diketahui memiliki masalah dalam pengetahuan keuangan, investasi, asuransi, tabungan serta pinjaman, pendapatan mereka sebagian besar digunakan untuk belanja bukan berinvestasi.

\subsubsection{Pengaruh Tahun Masuk terhadap Literasi Keuangan Mahasiswa}

Berdasarkan dari hasil pengujian tersebut dapat menunjukkan bahwa koefisien regresi variabel tahun masuk/angkatan sebesar 1,138 bertanda positif, artinya tahun masuk/angkatan dapat meningkatkan literasi keuangan. Hasil dari uji t menunjukkan bahwa nilai t-hitung sebesar 2.128 lebih besar dari t-tabel sebesar 1,976 artinya variabel tahun masuk berpengaruh positif terhadap literasi keuangan mahasiswa dan tahun masuk memiliki pengaruh yang signifikan terhadap literasi keuangan mahasiswa. Dapat dilihat pada tabel 4.15 diketahui nilai t-hitung sebesar 2,128 dan probabilitas (p) $0,035<0,05$. Hasil dari penelitian ini dapat disimpulkan bahwa tahun masuk berpengaruh positif dan signifikan terhadap literasi keuangan, sehingga hipotesis ketiga ditolak. Berdasarkan tabel 4.4 dapat diketahui jika mahasiswa angkatan lama/senior (2017-2018) memiliki tingkat literasi keuangan yang lebih rendah dibanding dengan mahasiswa awal/baru masuk (2019-2020) karena semakin muda angkatan maka semakin tinggi tingkat literasi keuangan mahasiswa.

Penelitian ini tidak sejalan dengan studi Kusumawardhani et al., (2020) menjelaskan bahwa tahun masuk memiliki pengaruh negatif terhadap tingkat literasi 
keuangan. Mahasiswa angkatan lama (senior) tingkat literasi keuangannya lebih tinggi dari pada mahasiswa angkatan baru ksrena mahasiswa angkatan lama memiliki kesempatan lebih lama untuk mempelajari beraneka ragam mata kuliah, mengikuti berbagai seminar-seminar dan memiliki pengalaman lebih banyak dari pada mahasiswa angkatan baru/ masuk di perguruan. Penelitian ini didukung dengan penelitian yang dilakukan oleh Faida (2019) yang menjelaskan bahwa Tahun masuk berpengaruh terhadap minat investasi.

\subsubsection{Pengaruh Pendapatan Terhadap Literasi Keuangan Mahasiswa}

Berdasarkan hasil dari pengujian tersebut dapat menunjukkan bahwa koefisien regresi variabel pendapatan sebesar $-0,752$ bertanda negatif artinya pendapatan yang diperoleh dan jumlah uang saku yang diterima setiap bulannya meningkat maka literasi keuangan akan turun. Hasil dari uji t menunjukkan nilai t-hitung sebesar 2,127 lebih besar dari ttabel besar 1,976 artinya variabel pendapatan berpengaruh negatif terhadap literasi keuangan dan maka pendapatan memiliki pengaruh yang signifikan terhadap literasi keuangan mahasiswa. Dapat dilihat pada tabel 4.15 diketahui bahwa nilai t-hitung sebesar 2.127 dan probabilitas (p) $0,035<0,05$.

Hasil penelitian dapat disimpulkan bahwa pendapatan berpengaruh negatif dan signifikan terhadap literasi keuangan mahasiswa, sehingga penelitian ini ditolak. Penelitian ini didukung oleh penelitian yang dilakukan oleh Susanti, (2016) dapat diketahui jika pendapatan berpengaruh negatif signifikan terhadap literasi keuangan mahasiswa sebesar (-0,585), hasil penelitian Hartanti (2018); Worthington (2006); Brushan et al., (2013) tidak sejalan karena menunjukkan bahwa pendapatan berpengaruh positif signifikan terhadap tingkat literasi keuangan. Margaretha \& Sari (2015) juga hasil penelitiannya menunjukkan bahwa pendapatan berpengaruh terhadap tingkat literasi keuangan para pengguna kartu kredit. Penelitian Faidah (2019) yang menjelaskan bahwa tahun masuk, pendapatan dan IPK mahasiswa berpengaruh dan signifikan terhadap minat investasi.

\subsubsection{Pengaruh Tempat Tinggal Terhadap Literasi Keuangan Mahasiswa}

Berdasarkan hasil pengujian tersebut dapat menunjukkan bahwa koefisien regresi dari tempat tinggal sebesar 1,897 bertanda positif, artinya tempat tinggal dapat meningkatkan literasi keuangan. Hasil uji t menunjukkan nilai t-hitung sebesar 2.566 lebih besar dari ttabel sebesar 1,976, artinya tempat tinggal berpengaruh positif terhadap literasi keuangan mahasiswa dan tempat tinggal berpengaruh secara signifikan terhadap literasi keuangan mahasiswa. Dapat dilihat pada tabel 4.15 diketahui bahwa nilai t-hitung 2,566 dan probabilitas (p) $0,011<0,05$.

Sehingga dapat disimpulkan bahwa tempat tinggal berpengaruh positif dan signifikan terhadap literasi keuangan mahasiswa, sehingga penelitian ini diterima. Tingkat literasi keuangan mahasiswa memiliki perbedaan berdasarkan tempat tinggal. Mahasiswa yang bertempat tinggal bersama orang tua/keluarga (62\%) memiliki tingkat literasi keuangan yang lebih tinggi dibandingkan mahasiswa yang bertempat tinggal di kos/asrama/kontrak (38\%). Penelitian ini didukung oleh studi dari Nababan \& Sadalia (2012) mengungkapkan bahwa tingkat literasi keuangan pada mahasiswa dapat 
dipengaruhi oleh tempat tinggal seseorang. Namun, tidak sejalan dengan penelitian Maulani (2016) yang menjelaskan bahwa mahasiwa yang memiliki tingkat literasi keuangan lebih tinggi adalah mahasiswa yang tinggal sendiri (kos/asrama/kontrak).

\subsubsection{Pengaruh Perilaku Keuangan Terhadap Literasi Keuangan Mahasiswa}

Berdasarkan hasil pengujian pada tabel 4.15 menunjukkan bahwa koefisien regresi sebesar 0.842 bertanda positif, artinya perilaku keuangan dapat meningkatkan literasi keuangan. Hasil uji t menunjukkan bahwa nilai t-hitungsebesar 9,611 lebih besar dari ttabel sebesar 1,976, artinya perilaku keuangan berpengatuh positif dan memiliki pengaruh yang signifikan terhadap literasi keuangan mahasiswa, sehingga penelitian ini diterima. Dapat dilihat pada tabel 4.15 diketahui nilai t-hitung sebesar 9,611 dan probabilitas (p) $0,000<0,05$.

Penelitian ini didukung oleh studi Arianti (2020) yang menjelaskan bahwa perilaku keuangan memiliki pengaruh secara positif dan signifikan terhadap literasi keuangan. Menurut Nofsinger (dikutip dalam Manurung, 2012) mengungkapkan bahwa perilaku keuangan merupakan bagaimana cara manusia mempelajari secara aktual berperilaku dalam mengambil keputusan keuangan. Terkhusus bagaimana psikologi seseorang dapat mempengaruhi dalam mengambil keputusan keuangan, perusahaan dan pasar keuangan. Pada kedua konsep tersebut dapat disimpulkan bahwa perilaku keuangan adalah pendekatan yang digunakan seseorang untuk melakukan investasi atau berkaitan dengan keuangan (Manurung, 2012). Perilaku keuangan berpengaruh terhadap tingkat literasi keuangan karena dalam melakukan pengelolaan uang harus didasari oleh tanggung jawab dalam perilaku seseorang (Mabyakto, 2017).

Studi terdahulu dari Depiana (2017); Aisyah (2019) hasil dari penelitiannya menunjukkan bahwa literasi keuangan dapat mempengaruhi perilaku keuangan dalam mengambil keputusan investasi. Dibebut mempengaruhi karena jika tingkat pemahaman literasi keuangannya baik, maka perilaku keuangan dalam mengambil keputusan juga lebih baik (Depiana, 2017); (Aisyah, 2019). Literasi keuangan syariah dan literasi keuangan dasar dapat mempengaruhi perilaku keuangan (Ningtyas, 2019). Perilaku keuangan dapat mempengaruhi tingkat literasi keuangan mahasiswa S2 Universitas Sanata Dharma pada angkatan IV,V, VI, dan VII (Mabyakto, 2017).

\section{Simpulan}

Berdasarkan hasil penelitian dan pembahasan hipotesis penelitian diproleh informasi bahwa untuk jenis kelamin, usia, tahun masuk, pendapatan, tempat tinggal dan perilaku keuangan berdampak signfikan terhadap literasi keuangan mahasiswa. Literasi keuangan sangat penting bagi para mahasiswa untuk meningkatkan kemampuan dan pemahaman tentang keuangan sehingga mampu membuat keputusan keuangan dengan baik supaya semakin siap dalam menghadapi persaingan dalam bekerja maupun berkeluarga. Mahasiswa Fakultas Ekonomi Universitas Sarjanawiyata Tamansiswa memiliki tingkat literasi sebesar 69,73\% maka dapat diartikan jika mahasiswa memiliki pengetahuan literasi keuangan tergolong tinggi karena berada di atas 60\% namun hampir mencapai rendah (Chen \& Volpe, 1998). 
Penelitian yang dilakukan sudah diupayakan semaksimal mungkin, namun masih banyak kekurangan dan keterbatasan penelitian. Pertama, sampel dalam penelitian ini masih terbatas karena hanya dilakukan oleh mahasiswa aktif tahun ajaran 2020/2021 di Fakultas Ekonomi Universitas Sarjanawiyata Tamansiswa Yogyakarta saja, lebih baik jika sampel yang diambil meliputi mahasiswa dari semua Fakultas di UST seperti Fakultas Pertanian, FKIP, Teknik, Psikologi, atau bisa mengambil sampel dengan Unversitas lain, sehingga hasil dari penelitian dapat digeneralisasikan dalam lingkup yang lebih luas. Kedua, metode yang digunakan menggunakan kuesioner, sehingga sangat dimungkinkan datanya bersifat subyektif, akan lebih baik apabila ditambahkan dengan metode wawancara sehingga hasil yang diperoleh dalam penelitian lebih lengkap. Ketiga, Penelitian ini bisa mengungkapkan secara keseluruhan faktor-faktor yang dapat mempengaruhi literasi keuangan, karena hanya menemukan $41,4 \%$ faktor-faktor yang mempengaruhi literasi keuangan, sehingga masih terdapat 58,6\% faktor-faktor lain yang tidak diteliti dalam penelitian ini. Keempat, pengumpulan data menggunakan kuesioner, maka data yang diperoleh bersifat subyektif, akan lebih baik jika ditambah dengan metode wawancara sehingga hasil penelitian yang diperoleh lebih lengkap.

Penelitian ini dapat dijadikan sebagai bahan pemikiran, pertimbangan dan referensi peneliti selanjutnya, dengan menambah variabel pengelolaan keuangan dan kesejahteraan keuangan, sehingga mendapatkan penemuan yang beragam dan mengetahui hubungan dari ketiga variabel tersebut. Mahasiswa harus lebih proaktif untuk belajar kaitanya dengan aspek-aspek keuangan terutama pada aspek tabungan dan investasi karena aspek tersebut adalah jenis pengalokasian dana yang sangat memberikan manfaat di masa depan. Bagi pihak Fakultas UST diperlukannya informasi tambahan bagi mahasiswa tentang pengetahuan umum keuangan pribadi bisa melalui kuliah umum atau seminar mengenai konsep keuangan pribadi guna meningkatkan literasi keuangan dan kemampuan dalam mengelola keuangan pribadi mahasiswa. Menambah wawasan dan motivasi bagi mahasiswa supaya pendapatan yang diterima bisa lebih baik dan berasal dari usaha kerja keras sendiri.

\section{Referensi}

Aisyah, S. (2019). Analisis Pengaruh Tingkat Literasi Keuangan Terhadap Financial Attitude Dan Financial Behavior (Studi Kasus Pada Mahasiswa STIE Indonesia Banking School), Skripsi, STIE Indonesia Banking School.

Arianti, B. F., \& Azzahra, K. (2020), Faktor - Faktor Yang Mempengaruhi Literasi Keuangan: Studi Kasus Umkm Kota Tangerang Selatan, Vol. 9 No. 2, pp. 156-171.

Bhushan, P., \& Medury, Y. (2013), Financial Literacy and its Determinants. International Journal Of Engineering , Business And Enterprise Applications ( IJEBEA ), Vol. 4 No. 2, pp. 155-160.

Chen, H., \& Volpe, R. P. (1998), An analysis of personal financial literacy among college students, Financial services review, Vol. 7 No. 2, 107-128.

Depiana. (2017), Analisis Pengaruh Literasi Keuangan, Sikap Keuangan Dan Sosial Demografi Terhadap Perilaku Keuangan Karyawan Dalam Pengambilan 
Keputusan Investasi, Skripsi, Jurusan Manajemen, Fakultas Bisnis dan Ekonomi. Institut Informatika dan Bisnis Darmajaya.

Faidah, F. (2019), Pengaruh Literasi Keuangan Dan Faktor Demografi Terhadap Minat Investasi Mahasiswa, Journal of Applied Business and Economic, Vol. 5 No. 3, pp. 251-263.

Hamid, R. S., \& Patra, I. K. (2019), PENGANTAR STATISTIKA UNTUK RISET BISNIS DAN EKONOMI Konsep Dasar dan Aplikasi SPSS versi 25, CV. AA. RIZKY, Banten.

Hartanti, R. E. (2018), Pengaruh Usia, Jenis Kelamin, Tempat Tinggal, Pendidikan Dan Pendaparan Terhadap Tingkat Literasi Keuangan Asuransi Syariah (Studi Kasus Pada Pedagang Pasar Gede Hardjonagoro Solo), IAIN Surakarta.

Herawati, N. T. (2015), Kontribusi Pembelajaran di Perguruan Tinggi dan Literasi Keuangan Terhadap Perilaku Keuangan Mahasiswa, Jurnal Pendidikan dan Pengajaran, Vol. 48 No. (1-3), pp. 60-70.

Krishna, A., Rofaida, R., \& Sari, M. (2010), Analisis tingkat literasi keuangan di kalangan mahasiswa dan faktor-faktor yang mempengaruhinya (Survey pada Mahasiswa Universitas Pendidikan Indonesia), In Proceedings of the 4th International Conference on Teacher Education, Vol. 4 No. 1, pp. 552-560.

Kusumawardhani R., \& Cahyani PD, N. N. (2020), Analisis Perbedaan Tingkat Literasi Keuangan Antara Mahasiswa Fakultas Ekonomi Dan Mahasiswa NON-Ekonomi. MIX: Jurnal Ilmiah Manajemen, Vol. 10 No. 1, pp. 15-28.

Laily, N. (2016). Pengaruh Literasi Keuangan Terhadap Perilaku Mahasiswa Dalam Mengelola Keuangan. Journal Of Accounting And Business Education, Vol. 1 No. 4. Pp. 1-17.

Lusardi, A., \& Mitchell, O. S. (2011), Financial literacy around the world: an overview, National Bureau of Economic Research Working Paper Series, (17107), Doi: $10.3386 / w 17107$.

Mabyakto, G. (2017), Analisis Tingkat Literasi Keuangan Mahasiswa, Skripsi, Universitas Sanata Dharma, Yogyakarta.

Manurung, A. H. (2012), Teori Perilaku Keuangan (Behaviour Finance), Economis of Management, Vol 41 No. 4, pp. 1-13.

Margaretha, F., \& Pambudhi, R. A. (2015), Tingkat literasi keuangan pada mahasiswa S1 fakultas ekonomi, Jurnal Manajemen dan Kewirausahaan, Vol. 17 No. 1, pp. 7685 .

Margaretha, F., \& May Sari, S. (2015), Faktor Penentu Tingkat Literasi Keuangan Para Pengguna Kartu Kredit Di Indonesia, Jurnal Akuntansi Dan Investasi, Vol 16 No. 2, pp. 132-144.

Maulani, S. (2016), Analisis Faktor-Faktor Yang Mempengaruhi Literasi Keuangan (Studi Pada Mahasiswa Jurusan Manajemen Fakultas Ekonomi Universitas Negeri Semarang Aktif Semester Genap Tahun, Skripsi, Jurusan Manajemen, Fakultas Ekonomi, Universitas Negeri Semarang.

Nababan, D., \& Sadalia, I. (2012), Analisis Personal Financial Literacy dan Financial 
Behavior Mahasiswa Strata I Fakultas Ekonomi Universitas Sumatra Utara, Jurnal Media Informasi Manajemen, Vol. 1 No.1, pp. 1-16.

Ningtyas, M. N. (2019), Literasi Keuangan Pada Generasi Milenial, Jurnal Ilmiah Bisnis dan Ekonomi Asia, Vol. 13 No. 1, pp. 20-27.

Nurhayati, E., \& Wiharno, H. (2020), LITERASI KEUANGAN DI KALANGAN MAHASISWA (Survei Pada mahasiswa Universitas Kuningan), Jurnal Riset Keuangan Dan Akuntansi, Vol. 3 No. 2.

Nurulhuda, E. S., \& Lutfiati, A. (2020), Analisis Faktor-Faktor yang Mempengaruhi Literasi Keuangan, Kinerja: Jurnal Ekonomi dan Bisnis, Vol. 2 No. 2, pp. 111-134.

Pahrudin, P., Hakim, I. W., \& Shollina, S. (2018). Analysis of Student Financial Literation Levels Hamzanwadi University and Its Affecting Factors. JPEK (Jurnal Pendidikan Ekonomi dan Kewirausahaan), Vol. 2 No. 2, 118-129.

Rasyid, R. (2012). Analisis Tingkat Literasi Keuangan Mahasiswa Program Studi Manajemen Fakultas Ekonomi Universitas Negeri Padang. Jurnal Kajian Manajemen Bisnis, Vol. 1, pp. 91-106.

Rosacker, K.M, S. Ragothaman, \& M. Gillispie. (2009), Financial literacy of freshmen business school students, College Student Journal, Vol. 43, pp. 391-399.

Sakinah, G., \& Mudakir, B. (2018), Analisis Literasi Keuangan Mahasiswa S-1 Fakultas Ekonomika Dan Bisnis Universitas Diponegoro Angkatan 2014 - 2017, Jurnal Dinamika Ekonomi Pembangunan, Vol. 1 No. 2.

Susanti. (2016), Pengaruh Locus Of Control Internal Dan Pendapatan Terhadap Literasi Keuangan Mahasiswa, Jurnal Ekonomi Pendidikan Dan Kewirausahaan, Vol. 4 No. 1, pp. 5-17.

Ulfatun, Tatik, Udhma, Syafa'atul Umi,. \& Dewi, R. S. (2016), Analisis Tingkat Literasi Keuangan Mahasiswa Fakultas Ekonomi Universitas Negeri Yogyakarta Tahun Angkatan 2012-2014. Pelita, Vol. XI No. 2, pp. 1-13.

Wijayanti, W., Agustin, G., \& Rahmawati, F. (2016), Pengaruh Jenis Kelamin, IPK, dan Semester Terhadap Literasi Keuangan Mahasiswa Prodi S1 Ekonomi Pembangunan Universitas Negeri Malang, Jurnal Pendidikan Ekonomi, Vol. 9 No. 1, pp. 88-98.

Widayati, I. (2012). Faktor-Faktor Yang Mempengaruhi Literasi Finansial Mahasiswa Fakultas Ekonomi Dan Bisnis Universitas Brawijaya. ASSET: Jurnal Akuntansi Dan Pendidikan, Vol. 1 No. 5, pp. 89-99.

Worthington, A. C. (2006). Predicting Financial Literacy In Australia Predicting Financial Literacy In Australia. Vol. 15 No. 1, pp. 59-79. 